\title{
HVMANITAS
}

\section{A imagem do orador em Plínio o Antigo}

Autor(es): $\quad$ Oliveira, Francisco

Publicado por: Faculdade de Letras da Universidade de Coimbra, Instituto de Estudos

URL

persistente: URI:http://hdl.handle.net/10316.2/23016

DOI: $\quad$ DOI:http://dx.doi.org/10.14195/2183-1718_63_15

Accessed : $\quad$ 26-Apr-2023 02:58:13

A navegação consulta e descarregamento dos títulos inseridos nas Bibliotecas Digitais UC Digitalis, UC Pombalina e UC Impactum, pressupõem a aceitação plena e sem reservas dos Termos e Condições de Uso destas Bibliotecas Digitais, disponíveis em https://digitalis.uc.pt/pt-pt/termos.

Conforme exposto nos referidos Termos e Condições de Uso, o descarregamento de títulos de acesso restrito requer uma licença válida de autorização devendo o utilizador aceder ao(s) documento(s) a partir de um endereço de IP da instituição detentora da supramencionada licença.

Ao utilizador é apenas permitido o descarregamento para uso pessoal, pelo que o emprego do(s) título(s) descarregado(s) para outro fim, designadamente comercial, carece de autorização do respetivo autor ou editor da obra.

Na medida em que todas as obras da UC Digitalis se encontram protegidas pelo Código do Direito de Autor e Direitos Conexos e demais legislação aplicável, toda a cópia, parcial ou total, deste documento, nos casos em que é legalmente admitida, deverá conter ou fazer-se acompanhar por este aviso.

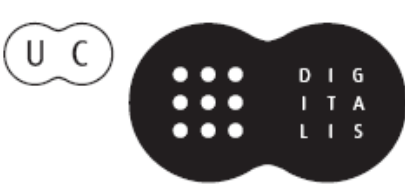


humanitas

Vol. LXIII

2011 


\title{
A IMAGEM DO ORADOR EM PLÍNIO O ANTIGO
}

\author{
Francisco Oliveira
}

Universidade de Coimbra ${ }^{1}$

\begin{abstract}
Resumo
A análise dos passos da História Natural que se reportam à palavra, à fala e à eloquência, mostram que Plínio é uma fonte importante para o conhecimento da retórica greco-romana. Na imagem do orador que é traçada, adivinha-se a definição de orador como vir bonus dicendi peritus, caracterizado no geral pela excelência, pela comitas e pela aversão ao ódio, numa concepção elitista em que o orador também aparece como promotor do ócio, do luxo e da cultura e em que a oratória se consagra como instrumento poderoso de cidadania e acção política.
\end{abstract}

Palavras-chave: luxo, orador, Plínio o Antigo, política, retórica.

\begin{abstract}
The analysis of passages in the Historia Naturalis which deal with words, speech and eloquence shows that Pliny is an important source for the understanding of ancient rhetoric. Pliny portrays the orator as vir bonus dicendi peritus, whose characteristics are excellence, comitas and an aversion to hatred; an elitist conception, in which the orator also promotes leisure, luxury and the very culture in which oratory is an instrument of citizenship and political action.

Key-words: luxury, orator, Pliny the Elder, politics, rhetoric.

${ }^{1}$ Trabalho desenvolvido no âmbito do plano quadrienal de actividades do Centro de Estudos Clássicos e Humanísticos da Universidade de Coimbra / FCT POC 2010. O presente artigo deve ser completado com a comunicação que apresentei em Logroño, com o título "El poder de la palabra en Plinio el Viejo", no XIII Congresso da Sociedade Espanhola de Estudos Clássicos.
\end{abstract}




\section{Introdução}

Plínio o Antigo (23/24 - 79 dC) é naturalmente mais conhecido pela sua História Natural do que pelas obras perdidas. Nestas, recordo dois títulos: Studiosi libri tres, que coleccionava sententiae e controversiae para uso dos oradores; e Dubius sermo, tratado gramatical onde tentava conciliar duas teorias, a analogia e a anomalia. ${ }^{2}$

Assim, verificamos que, ao abordar questões da linguagem e ao preocupar-se mesmo com aspectos técnicos do domínio da retórica, o autor se interessava por dois quesitos fundamentais para o tema que me proponho tratar, a imagem do orador.

\section{Imagem do orador}

Embora não reproduza a célebre definição de orador como vir bonus dicendi peritus ${ }^{3}$, Plínio situa os começos da oratória romana na mais remota antiguidade e atribui ao orador uma excelência e uma capacidade de afirmação que necessariamente privilegiam um estatuto social elevado, e nesse estatuto está incluída a riqueza.

A marca da excelência ocorre de forma lapidar a propósito de Asínio Polião, num passo onde a expressão principe oratore et cive 'orador e cidadão de primeira' justifica a sua classificação, de extremo relevo, como iudex ingenii 'árbitro do talento', juízo que exerceu quando pela primeira vez consagrou o busto de um literato numa biblioteca, no caso o de Varrão (Nat.7.115). ${ }^{4}$

De qualquer forma, a aliança entre oratória e exercício da cidadania remete para a constituição de cânones de valores onde a capacidade oratória figura ao lado de valores militares, civis e artísticos. E mais do que esse facto, o interessante é que tais cânones já constam da ideologia tradicional

${ }^{2}$ Cf. Plin. Nat. pr.28 (autocitação): libellos, quos de Grammatica edidi ...

${ }^{3} \mathrm{Na}$ verdade, Plínio não nega a excelente qualidade do orador Tucídides, apesar de anotar que fora acusado de falta de coragem militar, exilado pelos Atenienses e perdoado pelos seus méritos de historiador (Nat.7.111: eloquentiam mirati cuius virtutem damnaverant ' admirando a eloquência daquele cuja coragem haviam condenado').

${ }^{4} \mathrm{O}$ comentário de Plínio aproveita para valorizar a glória das letras em comparação com as condecorações militares. 
em épocas recuadas, nas quais quase não é costume assinalar a presença da oratória em Roma, como em Nat.7.139-140:

Q. Metellus in ea oratione, quam habuit supremis laudibus patris sui L. Metelli pontificis, bis consulis, dictatoris, magistri equitum, XVviri agris dandis, qui plurimos elephantos ex primo Punico bello duxit in triumpho, scriptum reliquit decem maximas res optimasque, in quibus quaerendis sapientes aetatem exigerent, consummasse eum: 140. voluisse enim primarium bellatorem esse, optimum oratorem, fortissimum imperatorem, auspicio suo maximas res geri, maximo honore uti, summa sapientia esse, summum senatorem haberi, pecuniam magnam bono modo invenire, multos liberos relinquere et clarissimum in civitate esse; haec contigisse ei nec ulli alii post Romam conditam.

Naquele discurso que pronunciou aquando das derradeiras homenagens em honra de seu pai Lúcio Metelo, pontífice, duas vezes cônsul, ditador, mestre da cavalaria, quindecênviro para a distribuição de terras, Quinto Metelo, que, no triunfo da primeira Guerra Púnica fez desfilar numerosos elefantes, deixou escrito que que seu pai tinha alcançado as dez coisas mais extraordinárias e melhores, coisas que os sábios passavam a vida a almejar: de facto, quisera ser um guerreiro de primeira, o melhor orador, o general mais corajoso, realizar os mais altos feitos com auspícios próprios, deter a magistratura suprema, ser dotado de suprema sabedoria, ser considerado o supremo senador, alcançar uma grande riqueza por via honesta, deixar muitos filhos e ser o mais ilustre da cidade; isto acontecera-lhe a ele e a mais ninguém desde a fundação de Roma.

O facto de se tratar de uma laudatio fúnebre significa, a meu ver, um registo conservador de valores, uma vez que a própria cerimónia era altamente tradicional e visto que, num discurso fúnebre, como nos epitáfios, se tende a inscrever um ideário costumeiro e não novidades que no momento pudessem parecer, se não ofensivas, pelos menos não consensuais. Ou seja: este discurso, pronunciado no ano de $221 \mathrm{aC}$, sobre o perfil político e oratório de alguém que atingiria a maior visibilidade em meados do séc. III, inclui a oratória em lugar de relevo entre dez títulos de excelência, alguns todavia algo redundantes em relação a outros. ${ }^{5}$

${ }^{5}$ A cronologia apontada é ligeiramente divergente da de G. Kennedy 1972 
Na verdade, o cânone torna a aparecer três gerações mais tarde, agora depurado e situado na época da Catão o Censor (m. 149 aC), em Nat.7.100:

Ceteris virtutum generibus varie et multi fuere praestantes. Cato primus Porciae gentis tres summas in homine res praestitisse existimatur, ut esset optimus orator, optimus imperator, optimus senator, quae mihi omnia, etiamsi non prius, attamen clarius fulsisse in Scipione Aemiliano videntur, dempto praeterea plurimorum odio, quo Cato laboravit. itaque sit proprium Catonis quater et quadragiens causam dixisse, nec quemquam saepius postulatum et semper absolutum.

Nos restantes tipos de virtudes, houve muitos homens notáveis, e de variadas formas. Considera-se que Catão, o primeiro da gens Pórcia, se notabilizou pelas três coisas supremas num ser humano: o facto de ser o melhor orador, o melhor general, o melhor senador - coisas que, para mim, embora sem carácter de precedência, todavia parecem ter tido mais fulgor em Cipião Emiliano, tanto mais que este refreou o ódio contra numerosas pessoas enquanto Catão o cultivou. Assim, seja propriedade de Catão ter pleiteado uma causa quarenta e quatro vezes, e ter sido processado mais vezes do que qualquer outro, e sempre absolvido.

Esta referência a nova depuração do cânone em geração mais recente do que a de Catão (Cipião Emiliano morreu em 129 aC), torna clara a ideia de que tal cânone tinha raízes antigas e se fora aperfeiçoando ao longo do tempo. ${ }^{6}$

E se realmente avançarmos para o final da República e para o Alto Império, vamos encontrar duas imagens do orador altamente emotivas, a de Cícero e a de Tito.

No caso do Arpinate, o tom encomiástico logo decorre da inserção do elogio no elenco dos exemplos romanos de ingeniorum gloria 'glorificação do talento', onde Cícero sobressai de forma enfática (Nat.7.116-117):

37-38, para quem a capacidade oratória começou a figurar na lista das virtudes tradicionais nos finais do séc. III.

${ }^{6}$ Como recorda M. C. Alexander 2010 98, a ideia de que um romano distinto devia ser capaz de falar está profundamente imbuída na tradição romana. Para G. Kennedy 1972 41, este passo prova que a litigação era comum na época em causa. 
116. innumerabilia deinde sunt exempla Romana, si persequi libeat, cum plures una gens in quocumque genere eximios tulerit quam ceterae terrae. sed quo te, M. Tulli, piaculo taceam, quove maxime excellentem insigni praedicem? (...) 117. te dicente legem agrariam, hoc est alimenta sua, abdicarunt tribus; te suadente Roscio theatralis auctori legis ignoverunt notatasque se discrimine sedis aequo animo tulerunt; te orante proscriptorum liberos honores petere puduit; tuum Catilina fugit ingenium; tu M. Antonium proscripsisti. salve primus omnium parens patriae appellate, primus in toga triumphum linguaeque lauream merite et facundiae Latiarumque litterarum parens aeque (ut dictator Caesar, hostis quondam tuus, de te scripsit) omnium triumphorum laurea maiorem, quanto plus est ingenii Romani terminos in tantum promovisse quam imperii.

116. Além disso, são inumeráveis os exemplos romanos, se alguém quiser contá-los, pois uma só nação produziu mais varões exímios, de todo o género, do que as restantes terras. Mas que sacrilégio esquecer-me de ti, Marco Túlio, e com que distintivo te hei-de proclamar excelente no mais alto grau? (...) 117. Perante o teu discurso, as tribos abdicaram da lei agrária, isto é, do seu alimento; perante a tua capacidade de persuasão, perdoaram a Róscio, autor da lei teatral, e com magnanimidade aceitaram ser distinguidas com lugares separados; perante o teu pedido, aos filhos do proscritos repugnou candidatarem-se às magistraturas. Catilina fugiu do teu génio; tu proscreveste Marco António. Salve, tu que foste o primeiro de todos a ser chamado pai da pátria, o primeiro a merecer o triunfo da toga e a láurea da eloquência e igualmente pai da facúndia das letras do Lácio, como sobre ti escreveu o ditador César, outrora teu inimigo, uma láurea maior que a de todos os triunfos, tanto maior quanto mais vale ter alargado as fronteiras do génio romano do que as do império.

Conforme escrevi noutro lugar ${ }^{7}$, o passo assume uma tonalidade altamente emotiva através de processos de amplificação retórica como as anáforas tel tuum/ tu, laurea, primus, parens, conjugadas com a aliteração, a prosopopeia e a estrutura frásica bem marcada, e termina num sonoro e hiperbólico elogio da superioridade das letras, neste caso representadas pela oratória, sobre a arte militar. ${ }^{8}$

${ }^{7}$ Oliveira 1992 191-193.

${ }^{8}$ Da oratória de Cícero, são indiciados os seguintes discursos: Sobre a lei 
De certo modo, este elogio evoca o de Tito no prefácio da História Natural, como se verá logo pela recorrência de vocabulário ou ideias muito sugestivas sobre a sua excelência literária e retórica (ingenium, eloquentia, eruditio, facundia), embora a seriação de formas verbais (tonas, amas, es, excogitasti, ) seja mais estática (Nat. pr. 5-6 e 11):

(...) longius etiam summoves ingenii fascibus. fulgurar<e $>$ in nullo umquam verius dicta vis eloquentiae, tribunicia potestas facundiae. quanto tu ore patris laudes tonas! quanto fratris amas! quantus in poetica es! o magna fecunditas animi! quem ad modum fratrem quoque imitareris excogitasti. 6. Sed haec quis possit intrepidus aestimare subiturus ingenii tui iudicium, praesertim lacessitum? (...) 11. te quidem in excelsissimo generis humani fastigio positum, summa eloquentia, summa eruditione praeditum, religiose adiri etiam a salutantibus scio, et ideo cura $<\mathrm{n}>\mathrm{t}$, quae tibi dicantur ut digna sint.

(...) ainda mais te distancias com os fasces do teu génio. De ninguém alguma vez se disse, com mais rigor, que fulgura a força da sua eloquência, o poder tribunício da sua facúndia. Quantos louvores entoas, com tua boca, em honra de teu pai! Quanto amor tens pelo teu irmão! Quão grande és em capacidade poética! Oh que grande fecundidade de espírito! De que modo também imaginaste imitar o teu irmão! 6. Mas tal superioridade, quem poderá sem temor avaliá-la ao submeter-se ao julgamento do teu génio, sobretudo se é um julgamento provocado? (...) 11. Tu, na verdade, colocado no mais alto fastígio do género humano, dotado de suprema eloquência, de suprema erudição, sei que também és religiosamente invocado pelos que te vêm saudar, e por isso procuram que sejam dignas as palavras que te dedicam!

Assinale-se uma diferença abissal na excelência que a ambos é atribuída. Enquanto o talento de Cícero, valorado por outrem, é garantido pelo ingenii iudicium de Júlio César, o de Tito afirma-se inquestionável. Tito não é objecto de nenhum juízo valorativo de entidade outra, é ele que exerce um ingenii iudicium sobre a obra do próprio Naturalista. Isto é, Tito acaba por ter um atributo superior e divino, ínsito na sua natureza numinosa (religiose adiri a salutantibus ... dicantur), enquanto Cícero somente assume a superioridade de um paterfamilias (pater patriae). Trata-se, evi-

agrária, Sobre Otão, Sobre os filhos dos proscritos, Catilinárias e Filípicas. 
dentemente, da diferença entre um referente republicano e uma realidade imperial. Enquanto no primeiro caso a oratória é uma arma dinâmica e activa, aqui afigura-se mais como uma capacidade de exteriorização de sentimentos e, sobretudo, por ser combinada com a valoração da capacidade literária, continua a afirmar-se como um atributo essencial da liderança política.

O único exemplo evidente de orador que parece não ter um perfil ilustre é representado pelo liberto C. Fúrio Crésimo e remete para inícios do séc. II aC, se é verdade que Espúrio Albino terá sido pretor em 189 e cônsul em 186 aC. O assunto, que Plínio trata de forma bastante pessoal, tem a ver com o facto de as suas terras produzirem colheitas muito mais abundantes do que as dos vizinhos, os quais, por inveja, o acusam de lhes lançar mau-olhado (Nat.18.42-43):

42. quamobrem ab Spurio Albino curuli aedile die dicta metuens damnationem, cum in suffragium tribus oporteret ire, instrumentum rusticum omne in forum attulit et adduxit familiam suam validam atque, ut ait Piso, bene curatam ac vestitam, ferramenta egregie facta, graves ligones, vomeres ponderosos, boves 43. saturos. postea dixit: Veneficia mea, Quirites, haec sunt, nec possum vobis ostendere aut in forum adducere lucubrationes meas vigiliasque et sudores. omnium sententiis absolutus itaque est.

42. Eis o motivo porque, no dia de julgamento fixado pelo edil curul Espúrio Albino, receando ser condenado, ao ter de se apresentar ao voto das tribos, levou para o foro todas as alfaias agrícolas e para aí trouxe toda a sua criadagem, de boa saúde e, como diz Pisão, bem tratada e vestida, ferramentas extremamente bem feitas, enxadas sólidas, arados pesados, bois 43. fartos. Depois disse: "Os meus bruxedos, Quirites, são estes, e não é possível mostrar-vos ou trazer para o foro os meus serões, as minhas vigílias e canseiras". Em consequência, foi absolvido por votação unânime.

Este trecho, que começa por marcar a oposição de condição social entre o réu, e servitute liberatus, e o magistrado aristocrata, Spurio Albino curuli aedile, parece atestar o alargamento da base social de recrutamento dos oradores, que normalmente é costume situar um pouco mais tarde, e implicaria um tipo de oratória em que a actio teria maior importância, talvez porque tal alargamento também correspondia a um aumento da assistência aos julgamentos. Na verdade, Crésimo traz consigo tal séquito 
de adereços que exige um grande espaço de actuação e até um elemento de ópsis condizente com um estilo de oratória mais popular e emotivo, e também mais massificado?.

Se este alargamento tem ou não a ver com a questão dos honorários dos oradores, e em especial com o pagamento dos advogados, não fica explícito, parecendo todavia deduzir-se que Plínio não contestava a existência de réditos financeiros ou materiais pelo ensino da oratória ou pelo exercício da advocacia.

Assim, o Naturalista compraz-se em recordar, entre a glória atribuída aos génios, que Isócrates vendera um discurso por vinte talentos. O facto ter-se-ia passado em 374 aC, em Rodes, provavelmente no domínio da oratória política, se é verdade que se tratou de uma exortação dirigida a Nícocles a propósito da sua entronização como rei de Chipre (Nat.7.110). Também são registados os enormes proventos de Górgias de Leontino na sua docência de retórica (Nat.33.83: tantus erat docendae artis oratoriae quaestus), quando se regista ter sido o primeiro a colocar em Delfos, em honra própria, uma estátua de ouro maciço, cerca de 420-417 aC.

Todavia, nem sempre os réditos seriam os esperados, como no caso do mestre de retórica Asclepíades de Prusa, da época de Pompeu, o qual, descobrindo uma solução melhor, trocou a retórica pela medicina, aí aplicando a sua eloquência com sucesso estrondoso, numa verdadeira logoterapia que nem todos os médicos aceitavam (Nat.26.12-13) ${ }^{10}$ :

(...) Asclepiades aetate Pompei orandi magister nec satis in arte ea quaestiosus, ut ad alia quam forum sagacis ingenii, huc se repente convertit atque, ut necesse erat homini qui nec id egisset nec remedia nosset oculis usuque percipienda, torrenti ac meditata cotidie oratione blandiens omnia abdicavit ...

(...) na época de Pompeu, Asclepíades, mestre de oratória que não tirava proveitos suficientes nessa arte, como tinha dotes de sagacidade para coisas diferentes do foro ${ }^{11}$, de repente voltou-se para a medicina e, como se impunha

${ }^{9}$ A importância da actio, no caso o gesto manual, poderá ver-se também em Nat.34.87, a propósito do escultor Cefisódoto: fecit et contionantem manu elata 'também fez um orador com a mão erguida'.

${ }^{10}$ Celso, pr.1.39: morbos autem non eloquentiae sed remediis curari.

11 'Foro' representa aqui a oratória forense (cf. Nat.6.89, sobre Taprobana: non fora litesve esse; 18.42-43), que se desenvolvia genericamente no foro romano, 
a um indivíduo que não conhecia os remédios, que devem ser aprendidos pela vista e pela prática, abandonou tudo o resto para captar quotidianamente através de uma conversa calorosa e preparada ...

Verdade é que outras formas de proveito pela capacidade oratória ou pelo ensino da retórica, como a referência à oferta de uma estátua a Hortênsio, por Verres (Nat. 34.48), ou das duas taças cinzeladas à mão com que Germânico presenteia o orador e seu preceptor Cássio Salano, também não suscitam qualquer comentário derrogativo por parte do Naturalista. ${ }^{12}$

De qualquer forma, em Roma o estatuto social e o nascimento continuarão a fazer parte do património individual de cada personagem, particularmente daquelas que pertenciam à elite. Isso mesmo é registado por Plínio a propósito do ius imaginum, que com o correr dos tempos e das circunstâncias familiares se ia abrindo a personagens que eram arrivistas na família, suscitando reacções por parte de mentalidades mais conservadoras.

Um dos passos mais significativos dessa realidade tem a ver com o orador M. Valério Messala Corvino (64 aC - $8 \mathrm{dC}$ ), cujo elitismo desperta os comentários de Plínio, de mentalidade mais aberta (Nat.35.8):

Exstat Messalae oratoris indignatio quae prohibuit inseri genti suae Laevinorum alienam imaginem (...) sed pace Messalarum dixisse liceat etiam mentiri clarorum imagines, erat aliquis virtutum amor multoque honestius quam mereri, ne quis suas expeteret.

Chegou até nós o discurso indignado do orador Messala, no qual ele proibiu introduzir na sua família uma imagem estranha, dos Levinos. (...) Mas perdoem-me os Messalas o que vou dizer: alardear imagens de pessoas ilustres até significava um certo amor às virtudes e era muito mais honesto do que alguém fazer com que ninguém cobiçasse as suas.

Decorrente do seu estatuto social e económico e da sua visibilidade e influência, a imagem pública de notoriedade, com as correspondentes

para o efeito coberto por um véu por Marcelo, provavelmente em $23 \mathrm{aC}$, quando foi edil, para que os litigantes tivessem mais conforto sentados em seus lugares (cf. Kennedy 1972 17).

${ }^{12}$ Quintiliano, Inst.12.7.8-12 discute a matéria, aceitando remuneração justa quando necessária. 
honrarias públicas, chega ao ponto de os oradores servirem de marcos cronológicos, como em Nat.9.168 (aetate L. Crassi oratoris ante Marsicum bellum 'na época do orador Lúcio Crasso, antes da Guerra contra os Marsos'). ${ }^{13}$

Um dos aspectos mais inéditos dessa grande visibilidade social, que se pode classificar como vedetismo, está presente em histórias como a de Téssalo de Trales, o médico que, na época de Nero, fazia uso de uma violenta invectiva contra os outros médicos $\left(\right.$ Nat.29.9) ${ }^{14}$ :

(...) delentem cuncta placita et rabie quadam in omnis aevi medicos perorantem, quali prudentia ingenioque, aestimari vel uno argumento abunde potest, cum monumento suo, quod est Appia via, iatronicen se inscripserit. nullius histrionum equorumque trigarii comitatior egressus in publico erat, cum Crinias Massiliensis ...

(...) destruindo tudo o que então agradava e perorando com alguma raiva contra os médicos de todas as épocas; a sua prudência e génio podem ser largamente comprovados com uma única prova, o facto de no seu túmulo, que está situado na via Ápia, ter gravado que era um Iatronikes 'vencedor dos médicos'. Nenhum histrião ou auriga de uma triga de cavalos tinha maior séquito ao aparecer em público, quando Crínias de Marselha ...

O mesmo vedetismo se afirma a propósito de Pórcio Latrão (55 aC - 4 $\mathrm{dC}$ ), classificado como clarus inter magistros dicendi 'ilustre entre os mestres de retórica', cujos discípulos tomavam cominho para ficarem pálidos. Esta anedota faz pensar quer em imitação, quer em veneração do mestre, quer ainda na procura de um traço identitário da sua pertença à escola de Latrão. Qualquer das hipóteses implica uma alta valorização da imagem pública do retor e da sua escola (Nat.20.160). ${ }^{15}$

Que os oradores eram susceptíveis de visibilidade social depreendese de igual modo da sua inclusão em outros registos de factos dignos de memória (mirabilia), como sejam: a existência de uma tradição familiar contínua de três gerações de oradores na mesma família, como no caso da

${ }^{13}$ É como se substituissem aos magistrados epónimos.

${ }^{14}$ A ideia de popularidade ou favor também se encontra na história de Asclepíades (Nat.26.12-13 faventibus cunctis).

${ }^{15}$ Conhecemos esta característica da palidez dos discípulos de uma escola através de Aristófanes, Nuvens, 1112. 
família dos Curiões, entre os séculos III e I aC (Nat.7.133) ${ }^{16}$; a sorte diferente de dois oradores nascidos no mesmo dia, um com êxito político (M. Célio Rufo), outro pouco apreciado, o poeta neotério C. Licínio Calvo (Nat.7.165); os sonhos eróticos ou o priapismo do orador C. Licínio Calvo, curados com uma placa de chumbo (Nat.34.166); e a semelhança entre pessoas de condição diversa (Nat.7.55):

e diverso L. Plancus orator histrioni Rubrio cognomen inposuit, rursus Curioni patri Burbuleius itemque Messalae censorio Menogenes, perinde histriones. Surae quidem proconsulis etiam rictum in loquendo intractionemque linguae et sermonis tumultum, non imaginem modo, piscator quidam in Sicilia reddidit. Cassio Severo, celebri oratori, Armentari murmillonis obiecta similitudo est.

Pelo contrário, o orador Lúcio Planco deu o nome ao histrião Rúbrio; por sua vez, Burbuleio deu o nome a Curião, o pai, e Menógenes a Messala, de estatuto de censor, igualmente histriões. Na Sicília, um pescador reproduziu até o modo de falar, o entaramelar da língua e o atropelo da fala, não apenas a aparência do procônsul Sura. A Cássio Severo, orador célebre, foi verberada a parecença com o mirmilão Armentário.

Como se vê, este passo atesta a fama e a notoriedade tanto de oradores, onde podíamos incluir políticos, como de actores, atletas e gladiadores, pessoas de grande visibilidade social, que, no elenco dos casos de indivíduos extraordinariamente parecidos, ocupam metade das ocorrências. ${ }^{17}$

Num outro passo, que remete para a época de Nero, a notoriedade (clarior) é aumentada pelo acesso ao entourage do príncipe, ficando na penumbra se esse acréscimo de influência não lhe foi granjeado pelo próprio facto de ser orador ilustre (Nat.16.242: Passienus Crispus bis cos., orator, Agrippinae matrimonio et Nerone privigno clarior postea 'Passieno Crispo, duas vezes cônsul, orador, posteriormente mais célebre pelo seu casamento com Agripina e por ser sogro de Nero').

${ }^{16} \mathrm{Na}$ verdade, o mais antigo dos Curiões é situado no séc. III aC em Nat.7.139-140. A referência está incluída num item que engloba quatro tipos de personalidades: reis, vencedores olímpicos, oradores e príncipes do senado. Ou seja: liderança suprema, lazer, retórica, política.

${ }^{17}$ Um dos mais notórios casos de vedetismo é relatado em Plin. Nat.7.186, o de um admirador fanático que se lança sobre a pira de um auriga. 


\section{O orador como expoente do lazer, do luxo e da cultura}

A visibilidade social do orador, a sua origem, a sua capacidade política e económica traduzem-se numa relação directa com a produção artística e com uma vida de luxo, tornando-os, assim, simultaneamente promotores da cultura e da magnificiência construtiva, como no caso de Curião (Nat.33.116-120), e consumidores requintados ${ }^{18}$.

Esta relação entre retórica, política e valorização das artes e do luxo torna-se especialmente saliente nos finais da República e inícios do Império, quando se assiste em Roma a um extraordinário acréscimo de interesse pela cultura, realidade que naturalmente transparece na História Natural.

A oratória não foi indiferente a tal explosão, assumiu mesmo uma participação activa. Registo dois pronunciamentos do máximo interesse. $\mathrm{O}$ primeiro, é o de Marco Vipsânia Agripa, um varão rusticitati propior quam deliciis 'mais inclinado à rusticidade do que ao requinte', do qual fica anotado que (Nat.35.26):

Exstat certe eius oratio magnifica et maximo civium digna de tabulis omnibus signisque publicandis, quod fieri satius fuisset quam in villarum exilia pelli.

Na verdade, chegou até nós um discurso seu, magnífico e digno do mais preeminente dos cidadãos, acerca da facultação ao público de todas as pinturas, o que seria preferível a enviá-las para o exílio das villae.

Sem prejuízo do remoque de Plínio contra o próprio facto de o autor desta tão visionária proposta ter, afinal, comprado obras-de-arte de valor incalculável, certamente para as suas colecções particulares, estamos perante um exemplo em que a oratória se abre à massificação da cultura.

Trata-se da mesma oratória que, num consilium amicorum ou até um consilium principis havido na época de Augusto, defende, pela voz de Q. Valério Messala Corvino $(† 8 \mathrm{dC})$, o ensino da pintura a um membro da família dos Césares (Nat.35.21):

${ }^{18}$ Que a fama alcançada num domínio artístico pode favorecer outro domínio, é ideia explicitada a propósito de Pacúvio, poeta e pintor mural (Nat.35.20): Enni sorore genitus hic fuit clarioremque artem eam Romae fecit gloria scaenae 'Ele era filho de uma irmã de Énio e a glória alcançada no teatro tornou aquela arte mais famosa em Roma'. 
Fuit et principum virorum non omittendum de pictura celebre consilium, cum Q. Pedius, nepos Q. Pedii consularis triumphalisque et a Caesare dictatore coheredis Augusto dati, natura mutus esset. in eo Messala orator, ex cuius familia pueri avia fuerat, picturam docendum censuit, idque etiam divus Augustus comprobavit.

Realizou-se também um célebre conselho de varões de primeiro plano sobre pintura, o qual não deve ser omitido, pelo facto de Q. Pédio, neto do consular Q. Pédio, deixado pelo ditador César como co-herdeiro com Augusto, ser mudo de nascença. Nesse conselho, o orador Messala, a cuja família pertencia a avó da criança, foi de parecer que lhe deviam ensinar pintura, e também Augusto aprovou tal proposta.

Na verdade, Plínio entende, e de forma correcta, que a pintura subira no patamar da valorização social, a ponto de já ser aceitável que um pintor pudesse ser de nascimento ilustre, e não é sem importância que a defesa desse ponto de vista seja classificada como oratio.

Este relacionamento de oradores com o lazer, o requinte e as criações do espírito dá-se em todos os domínios sociais e artísticos, da vida cultural à quotidiana, da cerâmica à estatuária, da culinária à aquicultura. Eis o elenco dos passos onde tal realidade se insinua.

- Nat.9.172: o orador Quinto Hortênsio Hórtalo (114-49 aC) gostava tanto de uma moreia que tinha no seu viveiro, que chorou a sua morte;

- Nat.10.45: foi também ele, por ocasião da recepção pela sua entrada no colégio sacerdotal, quem primeiro fez servir um pavão;

- Nat.10.52: Messalino Cota, orador e filho do orador Messala (séc. I dC), criou a moda de tostar as palmas das patas dos gansos e de enfeitá-las com cristas de galos;

- Nat.17.2: ambos censores em 92 aC, o orador M. Licínio Crasso, de grande sentido de humor, é invectivado pelo seu rival Gneu Domício Aenobarbo, também orador e homem severo, pelo facto de este possuir uma domus magnifica no Palatino, onde pela primeira vez em Roma colocara colunas de mármore estrangeiro; ambos eram das famílias mais nobres; 
- Nat.33.25: Demóstenes, summus Graeciae orator, usava um anel de ouro que escondia o veneno com que se teria suicidado por $322 \mathrm{aC}$;

- Nat.33.50: uso da retórica para moralizar, particularmente por parte de censores: o orador Messala invectiva o triúnviro António pelo facto de este usar vasos de ouro para fazer as suas necessidades, acusação que constará da literatura panfletária lançada contra Marco António em 32 aC;

- Nat.33.140: o orador aticista C. Licínio Macer Calvo (82-47 aC) clama contra vasilhame de cozinha de prata;

- Nat.33.147: contra a paixão por utensílios de prata caríssimos, Plínio recorda o caso do orador L. Licínio Crasso, que comprara duas taças cinzeladas por Mentor, ao preço de 100.000 sestércios, que não usava por vergonha (verecundia);

- Nat.34.6: Cícero, Marco António e Verres envolvidos em vinganças por causa de um bronze de Corinto;

- Nat.34.14: os herdeiros do orador L. Crasso puseram à venda leitos de mesa guarnecidos com bronze de Corinto;

- Nat.34.47: o orador Cássio Salano recebe de Germânico, de quem fora perceptor, duas taças cinzeladas à mão por Cálamis;

- Nat.34.48: numa altercação com o orador Hortênsio durante o julgamento de Verres, Cícero recorda que Hortênsio tem em casa um bronze de Corinto representando uma esfinge;

- Nat.35.25, sobre o apreço por pinturas estrangeiras, numa tirada com humor, do orador Crasso: Hinc enim ille Crassi oratoris lepos agentis sub Veteribus; cum testis compellatus instaret: dic ergo, Crasse, qualem me noris? talem, inquit, ostendens in tabula inficetissime Gallum exerentem linguam 'Daí aquele chiste do orador Crasso ao advogar nas Tabernas Velhas; quando uma testemunha, ao ser interrogada, o interpelou com um "Diz lá, Crasso, conheces-me de algum lado?!", respondeu "Dali!", apontando para um Gaulês que, numa pintura, deitava a língua de fora, sem qualquer graça'.

- Nat.35.73: vários oradores louvam a Ifigénia Velada pintada por Timanto, pela sua capacidade de exprimir sentimentos de tristeza;

- Nat.35.130: o orador Hortênsio pagou 144.000 sestércios por uma pintura de Cídias que representava os Argonautas. 
- Nat.35.163-164: Vitélio é postumamente vituperado por C. Licínio Muciano, contemporâneo de Galba e de Otão e apoiante eficaz de Vespasiano, a propósito da enorme travessa de cerâmica que mandara fabricar, ao preço de 1.000 .000 de sestércios, exemplo de luxuria extrema;

- Nat.36.7: o orador L. Crasso foi o primeiro a ter colunas de mármore estrangeiro.

Estes dados permitem entrever o relacionamento da oratória com a legislação sumptuária, na qual os censores têm papel dominante. A finalidade moralizadora das suas intervenções neste domínio parece recorrer a um discurso com um certo pathos, talvez para movere mais eficazmente, já que os respectivos instrumentos de coacção e persuasão eram frouxos. ${ }^{19}$

Interessante, pela sua antiguidade, por 290/280 aC, é a referência ao discurso do triunfador Mânio Cúrio Dentato, vencedor dos Samnitas e de Pirro, que, numa contio 'assembleia' considerou perigoso todo o cidadão que não se contentasse com sete geiras de terra (Nat.18.18).

Catão o Censor é o exemplo saliente de intervenção pela palavra, umas vezes eficaz, outras nem tanto. De facto, Plínio louva Catão e o Senado pelo pronunciamento a favor da expulsão dos médicos estrangeiros (Nat.29.16 e 20), que de facto se efectivou, e recorda o seu pronunciamento contra o consumo de coirato de javali (Nat.8.210: orationes aprunum exprobant callum). Mas também anota a sua incapacidade de controlar o luxo das mulheres, mesmo quando gritava mais do que elas. De facto, ao recordar a cruzada dos censores Públio Cornélio Cipião e M. Popílio, no ano de $158 \mathrm{aC}$, contra as estátuas privadas de ex-magistrados ou de candidatos à monarquia, matéria incluída na categoria da ambição política, Plínio regista o desaire do próprio Catão, como censor eleito em 184, ao tentar proibir, com acrimónia, as estátuas femininas (Nat.34.30-31):

Exstant Catonis in censura vociferationes mulieribus statuas Romanis in provinciis poni; nec tamen potuit inhibere quo minus Romae quoque ponerentur, sicuti Corneliae Gracchorum matri ...

${ }^{19}$ De qualquer forma, Nat.17.32 deixa supor momentos em que a oratória seria de uso junto dos censores e era certamente dominada pelos mesmos, como no caso do edil César Vopisco, ao defender a sua causa perante os censores (cum causam apud censores ageret). 
Chegaram até nós as vociferações de Catão, durante a sua censura, pelo facto de nas províncias se erigirem estátuas a mulheres; e ele nem sequer conseguiu evitar que também em Roma fossem erigidas, como a de Cornélia mãe dos Gracos ...20

\section{Oratória como instrumento de acesso ou conservação do poder}

Embora se pudesse defender que, inevitavelmente, todo o magistado romano tinha de ser orador, e que seria seguramente importante a sua palavra na presidência de assembleias, nas assembleias em geral e nos julgamentos e processos em especial, rastreei somente casos em que há referência explícita ao uso da palavra, tendo orientado a pesquisa por terminologia como censere, contio, contionare, dicere, eloquentia, eloqui, facundia, lingua, orare, oratio, oratorius, perorare, peroratio, persuasio, persuadere, abrindo raras excepções. Observe-se que nem rhetor nem rhetorica aparecem no texto de Plínio.

Que a palavra e a oratória constituíam um instrumento na luta pelo poder, depreende-se facilmente do exercício de qualquer dos géneros de discurso: o forense, com a oportunidade de atacar inimigos políticos nos tribunais e no senado; o deliberativo ou político, com intervenções em instâncias de decisão, como assembleias do povo e senado, e eventualmente em contiones militares; e o epidíctico ou demonstrativo, com exercícios de laus nas suas diversas modalidades, incluindo laudationes fúnebres e autoelogio, e de vituperatio ou denegrimento.

Essa relação estreita fica também comprovada pela intercepção do campo semântico da retórica com o do léxico da simpatia e da antipatia política, e decorre da posição social e económica dos oradores, pois, como foi dito, o nascimento e a riqueza são um importante instrumento de poder nas sociedades clássicas.

E numa primeira verificação, deve observar-se que o campo da oratória se cruza com o da cidadania e da política, como quando Asínio Polião é qualificado como principe oratore et cive 'orador e cidadão de primeira' (Nat.7.115).

No caso de Cícero, a excelência oratória e a superioridade política partilham a mesma metáfora da paternidade: primus omnium parens patriae Ópia.

${ }^{20}$ A sua cruzada contra as mulheres já vinha de $195 \mathrm{aC}$, quando atacou a lei 
appellate, primus in toga triumphum linguaeque lauream merite et facundiae Latiarumque litterarum parens aeque 'o primeiro de todos a ser chamado pai da pátria, o primeiro a merecer o triunfo da toga e a láurea da eloquência e igualmente pai da facúndia das letras do Lácio’ (Nat.7.117).

O mesmo se diga da enunciação dos já referidos cânones de virtudes, onde optimus orator 'o melhor orador' vem a par com terminologia referente a cargos, em especial senatoriais, e com acção política, tanto em Nat.7.100 como em 7.139-140, passos já transcritos. Esta associação de campos semânticos é registada em casos tão curiosos como o dos exemplos de felicidade (Nat.7.133) e de parecenças (Nat.7.55), com a selecção de material relativo a domínios que ilustram o nosso propósito: campo artístico, do desporto e do lazer; capacidade bélica; acção política a nível de liderança suprema ou de participação em órgãos ou magistraturas; capacidade oratória.

A eficácia política da oratória e da palavra revelam-se em situações tão diversas quão significativas. Assim, e avançando por ordem cronológica, comecemos pelo ano de 211 aC e pela campanha na Hispânia na II Guerra Púnica, contra Asdrúbal, com Plínio a recordar a contio de L. Márcio aos seus soldados, exortando-os a vingarem os dois Cipiões mortos em combate (Nat.2.241).

Também de virtus bélica trata o exemplo de M. Sérgio Silo. Este herói extraordinário perdera a mão direita em combate, mas, tendo-a substituído por uma prótese de ferro, continuou a realizar feitos extraordinários. Todavia, tendo em conta interditos atávicos, que vedavam o acesso à categoria de sacerdote ao portador de alguma deficiência física, Sérgio vê contestada pelos colegas de magistratura a sua capacidade para tomar augúrios. Em consequência, e supõe-se que com êxito político, o herói enumera todos os seus feitos no discurso que pronunciou, enquanto pretor, em $197 \mathrm{aC}$ (Nat.7.104-105: quae omnia ex oratione eius apparent habita cum in praetura sacris arceretur a collegis ut debilis). ${ }^{21}$

Por essa altura, quando Roma vai abrir-se extraordinariamente ao mundo helenístico, surge um dos registos mais interessantes e probatórios da relação entre oratória e política: a utilização de oradores e filósofos, ou oradores / filósofos, para missões diplomáticas. Trata-se de um apontamento importante também pelo facto de mostrar como, por esta via, já em tempos

${ }^{21}$ Cf. Sen. Con.4.2: Sacerdos non integri corporis quasi mali ominis res vitanda est. 
recuados, se dava a helenização da retórica em Roma, em especial da elite. ${ }^{22}$

De facto, quando a Roma se deslocavam legados estrangeiros, a audição fazia-se no Senado. Assim, em $167 \mathrm{aC}$, é reportada a morte imprevista de um embaixador, cujo nome seria Teedeto, o qual suscitou admiração geral ao discursar em defesa dos Ródios (Nat.7.182: in senatu magna cum admiratione oraverat).

Já aquando da célebre embaixada de filósofos, que, em $155 \mathrm{aC}$, integrava Carnéades, as audições no Senado foram completadas com arengas públicas que impressionaram vivamente e são largamente relatadas no livro III do Tratado da República de Cícero. Vejamos como Plínio se lhe refere (Nat.7.112-113):

Cato censorius in illa nobili trium sapientiae procerum ab Athenis legatione audito Carneade quam primum legatos eos censuit dimittendos, quoniam illo viro argumentante quid veri esset haut facile discerni posset.

Catão o Censor, naquela célebre embaixada ateniense de três chefes de escolas de filosofia, ao ouvir Carnéades, de imediato foi de parecer que aqueles embaixadores deviam ser recambiados, uma vez que, quando aquele varão argumentava, não era fácil discernir onde estava a verdade.

A III Guerra Púnica proporciona nova demonstração da eficácia do discurso persuasivo, com o exemplo notável do mesmo Catão o Censor, que em todas as sessões do Senado reclamava veementemente a destruição de Cartago, mas que só persuadiu quando recorreu à actio, gerando uma reacção imediata (Nat.15.74-75):

74. Sed a Catone appellata iam tum Africana admonet Africae ad ingens docimentum usi eo pomo. namque perniciali odio Carthaginis flagrans nepotumque securitatis anxius, cum clamaret omni senatu Carthaginem delendam, adtulit quodam die in curiam praecocem ex ea provincia ficum ostendensque patribus: Interrogo vos, inquit, quando hanc pomum demptam putetis ex arbore. 75. cum inter omnes recentem esse constaret: Atqui tertium, inquit, ante diem scitote decerptam Carthagine. tam prope a moeris habemus hostem! statimque sumptum est Punicum tertium bellum.

${ }^{22}$ Cf. Kennedy 197235 ss. 
74. Mas o figo que já Catão chamava africano faz lembrar que ele usou esse fruto para uma impressionante ilustração da África. De facto, inflamado por um ódio destrutivo contra Cartago e ansioso pela segurança dos descendentes, ao reclamar em cada sessão do senado que Cartago devia ser destruída, certo dia trouxe dessa província um figo temporão para a cúria e, mostrando-o aos senadores, exclamou: "Pergunto-vos: quando julgais que este fruto foi tirado da sua árvore?" 75. Como todos concordassem que era fresco, disse: "Pois ficai a saber que foi colhido há três dias em Cartago, tão perto das nossas muralhas temos o inimigo!" E de imediato foi declarada a terceira Guerra Púnica...

Da época de Catão até ao final da República, a relação entre retórica e poder é naturalmente aguda, passando por períodos tão agitados como as épocas dos Gracos, de Mário e Sila, enfim de Cícero, que aparecerá como o expoente máximo da intervenção política através da palavra.

Antes dele, e considerado superior a Catão, já brilhara Cipião Emiliano $(\dagger 129 \mathrm{aC})$, 'o melhor orador, o melhor general, o melhor senador... tanto mais que refreou o ódio contra numerosas pessoas enquanto Catão o cultivou'23. Provavelmente este 'ódio' tem a ver com o uso de perseguição forense, na figura de acusador e de acusado, implícita na menção do facto de 'ter pleiteado uma causa quarenta e quatro vezes, e ter sido processado mais vezes do que qualquer outro, e sempre absolvido' (Nat.7.100).

Coeva de Cipião Emiliano é a história de L. Hostílio Mancino, que, depois da destruição de Cartago, em 146 aC, encontrou na combinação de pintura e narrativa um meio de eficaz promoção pessoal (Nat.35.23):

Non dissimilem offensionem et Aemiliani subiit L. Hostilius Mancinus, qui primus Carthaginem inruperat, situm eius oppugnationesque depictas proponendo in foro et ipse adsistens populo spectanti singula enarrando, qua comitate proximis comitiis consulatum adeptus est.

Não diferente foi a ofensa praticada contra Emiliano por L. Hostílio Mancino, o primeiro que entrara em Cartago. Tendo exposto, no foro, pinturas com os ataques a esse local, e, sentado a seu lado, narrado cada feito à multidão de

${ }^{23}$ De Plu. Cato 18-19 deduz-se a divergência de opiniões e consequentemente as inimizades que Catão podia suscitar; cf. Tac. Ann.1.74, a propósito de Cepião Crispino e da relação odium / potentia. 
mirones, com tal acto de simpatia alcançou o consulado nos comícios que se seguiram.

Reúnem-se neste texto dois meios de persuasão, a pintura e a palavra, com um objectivo muito concreto, ganhar simpatia política (comitas) e, com ela, alcançar o poder que tem por fonte o povo.

Passando ao género epidíctico e à variante do auto-elogio, Plínio recorda o discurso de Pompeu sobre os seus próprios feitos, numa contio 'assembleia' datável de 69aC. e relativa ao seu $3^{\circ}$ triunfo (Nat.7.99: ut ipse in contione dixit, cum de rebus suis dissereret).

Por sua vez, em relação a Mitridates, o erudito rei do Ponto falecido em 63 aC, Plínio não só anota que falava 22 línguas, todas as dos seus súbditos, como o facto de, numa contio 'assembleia', ter discursado em cada uma delas sem intérprete, o que sugere que assim alcançava, pela via oratória, uma virtude imperial, a comitas ou affabilitas (Nat.7.88-89) ${ }^{24}$.

Sobre o edil Curião, tribuno em $50 \mathrm{aC}$, e as extravagantes construções de teatros gémeos suspensos para os jogos fúnebres em honra de seu pai, falecido em 53 aC, transcrevemos o comentário do Naturalista (Nat.36.116120):

et per hoc quaeritur tribuniciis contionibus gratia, ut pensiles tribus quatiat, in rostris quid non ausurus apud eos, quibus hoc persuaderit!

Eis o motivo pelo qual se pede às assembleias presididas por tribunos permissão para que as tribos fiquem a balouçar, suspensas: nos rostros, que ousadia não tentará junto daqueles aos quais persuadiu a fazer isto!

Com este exemplo de extrema ousadia política e de capacidade de persuadir as massas, aproximamo-nos do final da República e do Principado, onde perduram algumas das características da relação da retórica com o poder que vimos descrevendo. Assim, é atestada a rivalidade política entre um republicano independente, mas remetido ao silêncio, C. Asínio Polião (76 aC - $4 \mathrm{dC}$ ), que preparava discursos para atacar, pessoalmente

${ }^{24}$ A questão é inserida no capítulo sobre a memória, essencial ao orador e ao político, (cf. C. S. Stroup 2010 203-204), sendo nesse domínio elogiados Ciro, Lúcio Cipião, Cíneas, embaixador de Pirro, e anotada a invenção das mnemotécnicas (Nat.7.88-89; cf. Cic. Off. 2.48 para a relação entre retórica e comitas e affabilitas). 
ou através dos seus libertos, a memória do maleável Lúcio Munácio Planco, sucessivamente partidário de César, António e Octávio, quando o mesmo morresse. Sem sucesso, pois Munácio Planco destruiu preventivamente, pelo humor, a eficácia de tal denegrimento póstumo (Nat.pr.30-31).

Rivalidade política é também o motivo da intervenção de Vitélio como acusador no processo contra Pisão pelo envenenamento de Germânico no ano de $19 \mathrm{dC}(\text { Nat.11.187) })^{25}$ :

exstat oratio Vitelli qua Gnaeum Pisonem eius sceleris coarguit, hoc usus argumento palamque testatus non potuisse ob venenum cor Germanici Caesaris cremari. Contra genere morbi defensus est Piso.

Chegou até nós o discurso de Vitélio a acusar Gneu Pisão desse mesmo crime, usando o seguinte argumento, e amplamente atestado: que o coração do César Germânico não pudera ser cremado por causa de tal veneno. Em contrário, Pisão defendeu-se com a tipologia da doença.

Situado pouco depois, novo episódio ilustra a capacidade de granjear poder político, a propósito do orador e médico Vetio Valente, condenado à morte em 48 dC (Nat.29.8):

Vettius Valens adulterio Messalinae Claudii Caesaris nobilitatus, pariterque eloquentiae adesctatores et potentiae nanctus novam institui sectam.

Vétio Valente, famoso pelo adultério com Messalina, esposa do imperador Cláudio, tendo granjeado seguidores simultaneamente da sua eloquência e da sua influência, fundou nova seita. ${ }^{26}$

No início da dinastia Flávia, vemos Vitélio ser postumamente vituperado por C. Licínio Muciano, provavelmente no seu discurso de tomada de posse do $2^{\circ}$ consulado, no ano 70 , o que de algum modo caberia na categoria de denegrimento do predecessor como forma de elogiar o novo imperador (Nat.35.163-164: altero consulatu suo in conquestione exprobravit),

${ }^{25}$ Ver Suet. Cal. 1 ss.; Tac. Ann.2.55 ss.; 2.74; 3.10.

${ }^{26}$ Ver Tac. Ann.11.30-35. 
A verdade é que este imperador efémero, Aulo Vitélio, devia ter provocado o ódio de Muciano por razões políticas mas também por algum excesso de língua, como pode deduzir-se de uma observação de Plínio (Nat.35.165):

(...) M. Caelio credamus, qui linguam sic amputandam obiecit gravi probro, tamquam et ipse iam tunc eidem Vitellio malediceret.

(...) a acreditarmos em M. Célio, que propõs que a língua fosse dessa maneira amputada em caso de opróbrio grave, como se ele próprio, já na sua época, injuriasse o mesmo Vitélio. ${ }^{27}$

E, fechando o roteiro cronológico, vemos que excelência pessoal tem como representante máximo o futuro imperador Tito, o dedicatário da História Natural, cuja carta-prefácio nele espelha uma superioridade intelectual que o transforma em árbitro do talento (Nat. pr.5-6):

5. 'longius etiam summoves ingenii fascibus. fulgurar $<\mathrm{e}>$ in nullo umquam verius dicta vis eloquentiae, tribunicia potestas facundiae. quanto tu ore patris laudes tonas! quanto fratris amas! quantus in poetica es! o magna fecunditas animi! quem ad modum fratrem quoque imitareris excogitasti. 6. Sed haec quis possit intrepidus aestimare subiturus ingenii tui iudicium, praesertim lacessitum? (...) maiorem te sciebam, quam ut descensurum huc putarem.'

5. (...) ainda mais te distancias com os fasces do teu génio. De ninguém alguma vez se disse, com mais rigor, que fulgura a força da sua eloquência, o poder tribunício da sua facúndia. Quantos louvores entoas, com tua boca, em honra de teu pai! Quanto amor tens pelo teu irmão! Quão grande és em capacidade poética! Oh que grande fecundidade de espírito! De que modo também imaginaste imitar o teu irmão! ! 6. Mas tal superioridade, quem poderá sem temor avaliá-la ao submeter-se ao julgamento do teu génio, sobretudo se é um julgamento provocado? (...) Eu sabia que tu eras demasiado grande para pensar que ias descer até aqui.

${ }^{27} \mathrm{O}$ castigo proposto por Marco Célio Rufo, elogiado como orador em 7.165 e contemporâneo de Cícero (foi morto juntamente com Milão em 48aC), é paralelo à castração com um fragmento de cerâmica de Samos, tal como era praticada pelos sacerdotes da Grande-Mãe e por adúlteros e se encontra atestada em Lucílio, fr.279-281 e 282-283 M e em Hor. S.1.2.44-45. 
Neste passo tão subtil e cheio de entusiasmo, é afirmada a capacidade da eloquência (vis eloquentiae), a força da sua intervenção política, quer através do exercício do poder sobre os sujeitos (tribunicia potestas facundiae), quer através da promoção da harmonia na família imperial (quanto tu ore patris laudes tonas! quanto fratris amas!), quer, enfim, através da criação de uma imagem de bom governante, dotado da já antes mencionada virtude da comitas ou affabilitas (ut descensurum huc putarem 'para pensar que ias descer até aqui!').

\section{Conclusão}

A análise dos passos da História Natural que se reportam à palavra, à fala e à eloquência, mostram que Plínio é uma fonte importante para o conhecimento da retórica greco-romana em geral e também em casos específicos, como o valor da actio e do humor, a existência de uma retórica demagógica, a relação entre capacidade oratória e potentia, a remuneração da advocacia.

Na imagem do orador que é traçada, adivinha-se a definição de orador como vir bonus dicendi peritus, caracterizado no geral pela excelência, pela comitas e pela aversão ao ódio, numa concepção elitista em que o orador também aparece como iudex ingenii e promotor do ócio, do luxo e da cultura e em que a oratória se consagra como instrumento poderoso de cidadania e acção política, que se deve mover pelo amor, não pelo ódio.

Tanto para a época republicana, onde sobressai a figura de Cícero e a fixação progressiva de um cânone de excelência, como para a imperial, onde se distingue a personalidade de Tito, Plínio enfatiza a supremacia dos valores da palavra sobre os valores bélicos.

\section{Bibliografia}

M. C. Alexander (2010), "Oratory, Rhetoric, and Politics in the Late Republic" in W. Dominik - J. Hall (eds), A Companion to Roman Rhetoric. Oxford 98-108.

S. F. Bonner (1969), Roman Declamation in the Late Republic and Early Principate. Liverpool, 1949 repr.

G. Kennedy (1972), The Art of Rhetoric in the Roman World 300 B.C.A.D. 300. Princeton. 
Th. Koeves-Zulauf (1973), "Die Vorrede der plinianischen Naturgeschichte", WS 7 134-184.

F. Oliveira (1992), Les idées politiques et morales de Pline l'Ancien. Coimbra.

G. PASCUCCI (1980), "La lettera prefatoria di Plinio alla Naturalis Historia", InvLuc 2 5-39.

J. P. Small (2010), "Memory and the Roman orator" in W. Dominik - J. Hall (eds), A Companion to Roman Rhetoric. Oxford 195-206.

C. S. Stroup (2010), "Greek Rhetoric Meets Rome: Expansion, Resistance, and Acculturation" in W. Dominik - J. Hall (eds), A Companion to Roman Rhetoric. Oxford 23-37.

R. Wolverton (1964), "The Encomium of Cicero in Pliny the Elder", in Classical Medieval and Renaissance Studies in Honor of B. L. Ullman. I. Roma 159-164. 